\title{
Assessment of Heavy Metals Contamination in Near-Surface Dust
}

\author{
Zhongping Yang' ${ }^{1, *}$, Huakang $\mathrm{Ge}^{1,2}$, Wenxi Lu ${ }^{3}$, Yuqiao Long ${ }^{4}$ \\ ${ }^{1}$ School of Civil Engeinering, Chongqing Universtiy, Chongqing 400045, China \\ ${ }^{2}$ Key Laboratory of New Technology for Construction of Cities in Mountain Areas (Chongqing University), \\ Ministry of Education, Chongqing 400045, China \\ ${ }^{3}$ College of Environment and Resources, Jilin University, Changchun 130026, China \\ ${ }^{4}$ Nanjing Hydraulic Research Institute, Nanjing 210029, China \\ Received: 19 November 2014 \\ Accepted: 15 April 2015
}

\begin{abstract}
As a result of the continuous urbanization and industrialization in China over the last few decades, heavy metals have been continuously emitted into urban environments and now pose serious threats to human health. In the present study, an extensive urban near-surface dust survey was conducted in Changchun, China, to evaluate the current status of heavy metal contamination in urban dust and to identify the potential sources. A total of 232 samples were collected and the levels of $\mathrm{Cu}, \mathrm{Pb}, \mathrm{Zn}, \mathrm{Cd}, \mathrm{Hg}, \mathrm{As}, \mathrm{Cr}$, and the major elements were then determined. The results indicated that the urban dusts were enriched with metals, particularly $\mathrm{Cu}, \mathrm{Cd}, \mathrm{Zn}, \mathrm{Pb}$, and Hg. Principal component analysis (PCA) was employed to identify sources of heavy metals, and the results revealed distinctly different associations among the trace metals and the major elements in the urban dusts. The concentrations of $\mathrm{Cr}$ and $\mathrm{As}$ appeared to be controlled by natural factors. $\mathrm{Cu}$ and $\mathrm{Pb}$ were mainly from vehicle emissions. Zn primarily come from traffic sources, especially vehicle tires. Additionally, $\mathrm{Hg}$ primarily originated from coal combustion, while Cd was mainly associated with industrial sources. A revised pollution index for each metal and a Nemerow integrated pollution index (NIPI) of the seven metals were attributed to each sampling site to assess the degree of metal contamination. The results showed that the pollution indexes (PI) of each metal are not especially high. However, a significant degree of metal pollution exists in some urban dusts in Changchun, particularly for $\mathrm{Cu}, \mathrm{Cd}, \mathrm{Zn}$, and $\mathrm{As}$. The mean value of the Nemerow integrated pollution index (NIPI) of the seven metals also indicated that urban dusts in Changchun city were classified as having moderate levels of pollution. However, it should be noted that about $11 \%$ of all samples had a NIPI value above 3, suggesting a high level of contamination by metals. These findings indicate that more attention should be paid to metal pollution of the urban dusts in Changchun in the future.
\end{abstract}

Keywords: urban dust, heavy metals, Changchun city, pollution assessment

\section{Introduction}

The continuous urbanization and industrialization that has occurred in many countries over the last few decades has been accompanied by unprecedented environmental

*e-mail: yang-zhp@163.com changes. Several categories of contaminates, such as heavy metals $[1,2]$ and polycyclic aromatic hydrocarbons (PAHs) [3], etc., are continuously emitted into the terrestrial environment, thus posing a great threat to human health [3-5]. Nowadays, more and more people dwell in urban areas. Therefore, the changes of urban environment are crucially important for city dwellers. Heavy metal pollution of urban 
dust and soil is one of the fastest growing types of environmental pollution and is raising serious concerns of researchers because of the pollution accumulation and health risks [4, 6-11].

Urban soil and dust are important reservoirs of trace metal contaminants in urban environments [12, 13]. Meanwhile, compared with urban soils, urban dusts, as a special type of environmental medium, have been reported in many countries to contain toxic organic and inorganic pollutants, especially high levels of trace metals [1-4, 6-11]. These metals can remain in urban environments for a long time or be re-suspended into the atmosphere and thus pose a potential threat to local ecosystems and public health. The results of total metal loadings and $\mathrm{Pb}$ isotope ratios reveal that dust is much more sensitive than bulk surface soil to anthropogenic contamination in urban areas [14]. Therefore, urban dusts can reflect pollutants from multimedia, and were considered as an important environmental indicator of urban environmental pollution [7, 15].

Many previous studies have shown that heavy metal contents in street dusts are generally much higher than those in urban soils $[1,16]$. Long-term exposure to an urban dust environment that contains elevated concentrations of heavy metals would cause chronic damage through ingestion via the hand-mouth pathway, inhalation, and dermal contact $[1$, $3,5]$. It has been estimated that adults could ingest up to $100 \mathrm{mg}$ dust per day in dusty environments [17]. Children are usually exposed to greater amounts of dust than adults as a result of "pica" (the mouthing of non-food objects) and play behavior. Meanwhile, research indicates that dust transported and stored in the urban environment also has the potential to provide considerable loadings of heavy metals to receiving water and water bodies [18]. Therefore, several authors have stated that there is a growing need for increased knowledge, investigation, and assessment of trace metal contamination in urban dust $[9,10]$.

Numerous studies have tried to ascertain various aspects of heavy metal contamination in urban dust. These studies focused on element contents, fractionation and contamination assessment, particle-size and spatial distribution, and source identification. Although many studies have concentrated on the total levels of heavy elements in street dust, environmental and health effects of heavy metals in dust are dependent, at least initially, on the mobility and availability of the elements, and mobility and availability is a function of their chemical speciation and partitioning within, or on, dust matrices [10,19]. Previous studies also showed that the chemical fractionation patterns of heavy metals in urban dusts in different locations vary. Meanwhile, the high exchangeable phases of heavy metals in urban dust were found $[10,19]$.

Behavior and other properties of urban dust strongly depend on particle size distribution. Generally, toxic heavy metals were found to be mainly associated with fine particulates compared to coarse ones [20,21]. Based on spatial analysis, it was found that areas with highly elevated metal concentrations were generally located in industrial and residential areas, and roadside and crowded commercial districts. In contrast to heavy metals in urban soils, those in urban dust have many more possible sources, especially derived from anthropogenic sources. For urban dusts, the anthropogenic sources of heavy metals include traffic emissions such as vehicle exhaust particles [15, 22], tire wear particles [22, 23], weathered street surface particles, and brake-lining wear particles [22, 23], plus industrial emissions (power plants, coal combustion, metallurgical industry, auto repair shops, chemical plants, etc.) [8, 9, 15], domestic emissions, weathering of building and pavement surfaces, and other activities such as waste incineration. Multivariate statistical methods have commonly been applied to assess the sources of heavy metals in urban soils [7, 19]. The HRTEM/EDX approach, magnetic, and lead isotopes were also used to identify the source of dust particles in urban dust [13, 15, 24, 25]. Most recently, research also has focused on heavy metal pollution of the dust deposited on foliage [25, 26].

Despite numerous studies of heavy metal contamination in urban dust that have been conducted in developed countries and in some Chinese metropolitan areas, there is little information available regarding heavy metals contamination of urban dust in Changchun City, China. Little attention has been given to trace elements in the near-surface dust (1.5 $\mathrm{m}$ height above ground surface, which is considered the average breath height, was defined in the present study) which is the accumulative mixture of atmospheric particulate and surface dust for a relatively long time, and is much more easily touched and re-suspended [27, 28]. Meanwhile, research on near-surface dust has supplemented the research on air pollution of $0 \sim 5 \mathrm{~m}$, and has important significance in urban administration, urban planning, and the study of element transformative mechanisms in urban ecological environments. As the first heavy industrial base since the establishment of the P.R.C., Changchun has made great contributions to the economic development of China. The rapid economic development in Changchun over the last two decades, however, has led to a significant release of waste into the urban environment and placed great pressure on the local environment, including heavy metal contamination of urban soils and dust, such as $\mathrm{Cd}, \mathrm{Cu}, \mathrm{Pb}$, and $\mathrm{Zn}$ [27-30]. The environmental quality of Changchun is vital for future sustainable development. Therefore, a more detailed study is required to elucidate the environmental changes associated with the rapid economic growth that is occurring, as well as to find appropriate methods for sensible and responsible development to maintain a sustainable environment.

The present study was conducted to:

1) determine the concentrations of heavy metals $(\mathrm{As}, \mathrm{Cd}$, $\mathrm{Cr}, \mathrm{Cu}, \mathrm{Hg}, \mathrm{Pb}$, and $\mathrm{Zn}$ ) in near-surface urban dust collected from Changchun,

2) identify their natural or anthropogenic sources by principal component analysis (PCA),

3) assess the level of heavy metal contamination in the near-surface dust based on pollution index values and the Nemerow integrated pollution index (NIPI).

This information will be helpful to urban planners and environmental risk managers who seek to encourage responsible, environmentally friendly economic development strategies. 


\section{Materials and Methods}

\section{Study Site}

The study site is located in the urban area of Changchun, the capital of Jilin Province and an important social-economic center of northeastern China located in the hinterland of the Northeast Plain. The main urban area of this city consists of five administrative districts: Chaoyang, Lvyuan, Kuancheng, Erdao, and Nanguan (Fig. 1). The city spans $4,789 \mathrm{~km}^{2}$ and had an urban population of 4,876,500 in 2011, growing from approximately $1,643,000$ in 1980 and 2,110,000 in 1990 . The population density is about 3,295.6 per $\mathrm{km}$ in urban areas. The area is dominated by relatively flat topography with an altitude of 200 to $250 \mathrm{~m}$, and the area falls within the North Temperate Zone, which is characterized by a sub-humid climate with a continental monsoon. The annual average temperature of the region is $4.8^{\circ} \mathrm{C}$ and the average annual rainfall is $569.6 \mathrm{~mm}$. The prevailing wind direction is from the southwest to northeast throughout the year, and there is an annual average wind speed of $4.3 \mathrm{~m} / \mathrm{s}$. Urban land uses are primarily industrial, residential, and commercial. There were more than 0.617 million motor vehicles in the city in 2011, and this number has been increasing by 230 per day. In 2012, approximately 24.7 million tons of coal were consumed in the city. The major industries are the automotive industry, coal-fired power plants, metallurgy, iron and steel mills, machine manufacturing, electric and electronics manufacturing, and medicine. Most of the automotive industry is located in the northwestern and southwestern portions of the city, while the northern and eastern areas are dominated by metallurgy, coal-fired power plants, iron and steel mills, and some cement plants and other building material production facilities (Fig. 1). This study area has experienced substantial uncontrolled development over the past 30 years. The central part of the study area comprises the historic center district and is characterized by high residential and commercial activities and traffic levels. The southern region is the new district and comprises an important residential and educational area, with only a few industrial activities.

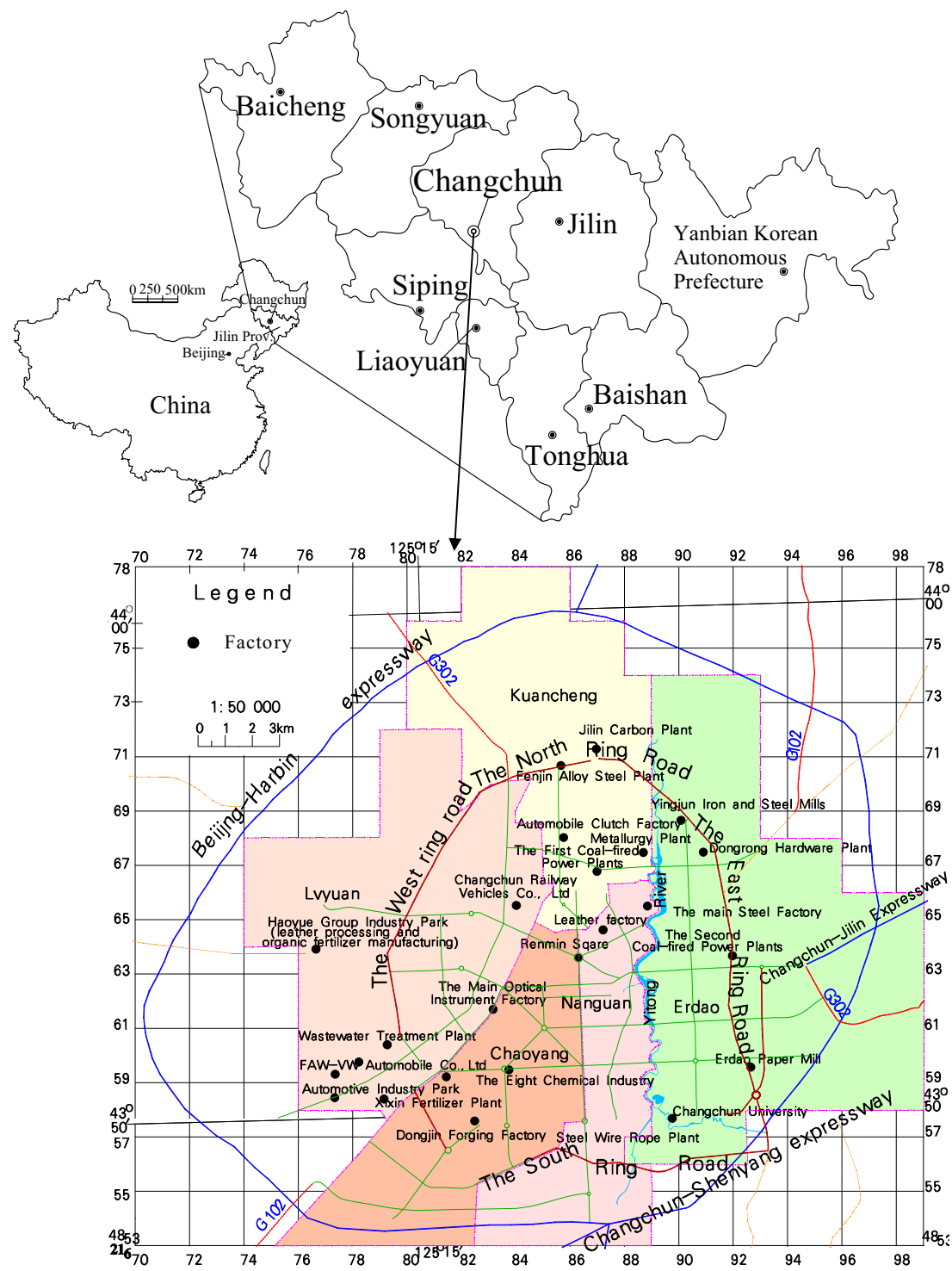

Fig. 1. Locations of Changchun are shown together with the communication network, the administrative division, and the main industries (only a few factories are shown because of the limited page space). 


\section{Sampling and Analysis}

In the present study, the scope of the sampling area focused on the urban area of Changchun, which has an area of $215 \mathrm{~km}^{2}$. According to the Specifications of the Multipurpose Regional Geochemical Survey carried out by the China Geological Survey (CGS) in 2005 and methods documented by [31], a systematic sampling strategy was adopted to provide a sampling scheme over the entire study area. The total area was divided into 215 cells of $1 \mathrm{~km} \times 1 \mathrm{~km}$ in size, within which the near-surface urban dust samples (about $1.5 \mathrm{~m}$ high above ground surface) were collected. A sampling density of one sample per $\mathrm{km}^{2}$ was adopted wherever possible in urban areas. Each of the dust samples consisted of about 3-5 sub-samples collected by sweeping all kinds of platform surfaces, mainly on nonmetallic windowsills using a clean plastic dustpan and brushes for each sampling site. The sampling data were chosen in April, the end of the dry spring season, and there was no rain when the samples were collected. Meanwhile, the sampling site was far from significant pollution sources such as main streets, construction sites, industrial factories, etc. Because the samples were collected from a nonmetallic platform and did not touch any metal tools during sampling and subsequent sample preparation and analysis, the impacts of platform and sampling tools on the content of heavy metals in dust were neglected. For each cell, a total of $30 \mathrm{~g}$ of dust was taken from the mixed samples using a quartile method. Overall, 232 samples were collected. The collected dust samples were stored in paper bags for transport and storage. The exact location (longitudes and latitudes) of each sample point was measured by a GPS instrument, and environmental observations were described during fieldwork (Figs. 1 and 2).

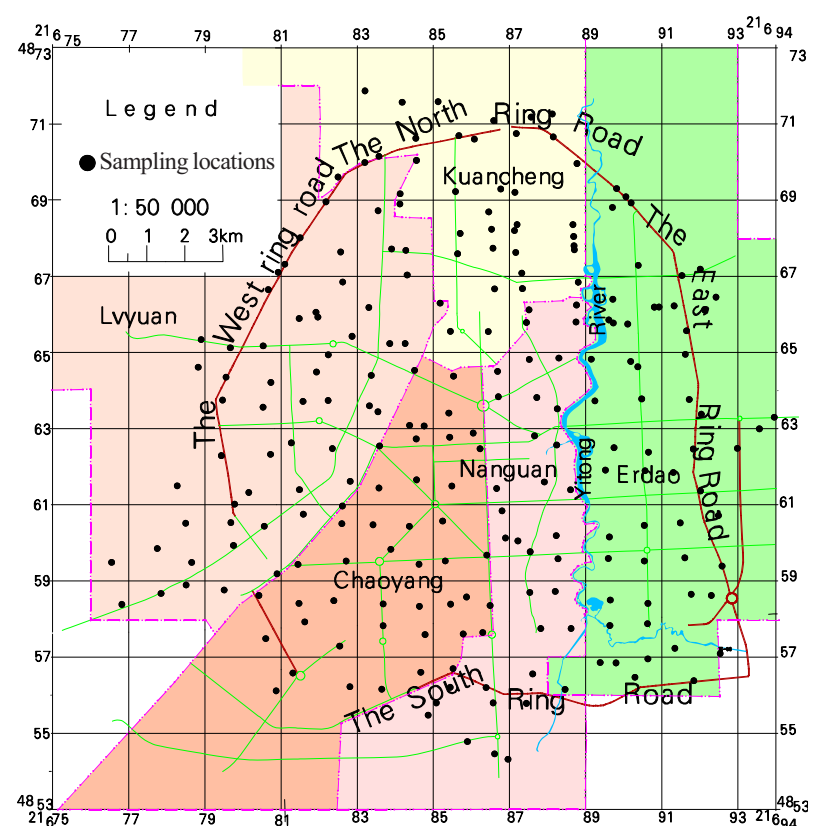

Fig. 2. Locations of sample sites in Changchun City.
The samples were air-dried naturally in a laboratory for about two weeks, after which they were sieved through a 20 -mesh polyethylene sieve $(<0.8 \mathrm{~mm})$ to remove stones, coarse materials, and other debris. A total of $20 \mathrm{~g}$ of dust was collected from the sieved samples using the quartile method and then stored in polyethylene bottles in a desiccator.

All analyses were completed in the lab of the Changchun Inspection and Testing Center of Geology and Mineral Resources, a subordinate research institute of the Ministry of Land and Resources of China. The prepared urban dust samples were ground in an agate mortar to pass through a 200-mesh sieve prior to analysis. For each sample, approximately $0.2 \mathrm{~g}$ of urban dust was digested using $\mathrm{HF}, \mathrm{HNO}_{3}$, and $\mathrm{HClO}_{4}$ for measuring the heavy metals and major elements concentrations. The total concentrations of As and $\mathrm{Hg}$ were analyzed by atomic fluorescence spectrometry (AFS, AFS-230E, Beijing, China), whereas Cd was measured by Graphite Furnace Atomic Absorption Spectrometry (GF-AAS, M6, thermo Elemental, USA), and the total concentrations of $\mathrm{Cu}, \mathrm{Pb}, \mathrm{Zn}, \mathrm{Cr}$, and the major elements ( $\mathrm{Mn}, \mathrm{Al}_{2} \mathrm{O}_{3}, \mathrm{CaO}, \mathrm{Fe}_{2} \mathrm{O}_{3}, \mathrm{MgO}, \mathrm{SiO}_{2}, \mathrm{~K}_{2} \mathrm{O}$, and $\mathrm{NaO}$ ) in soil samples were measured by $\mathrm{X}$-ray fluorescence spectrometry (XRF, ADVANT'XP ${ }^{+}$, ARL, Switzerland).

For each sample, approximately $10 \mathrm{~g}$ of a 20 -mesh sieved urban dust sample was weighed for measuring the $\mathrm{pH}$ of the dust. Values of $\mathrm{pH}$ were measured in $\mathrm{H}_{2} \mathrm{O}$ with a soil/solution ratio of $1: 2.5(\mathrm{~m} / \mathrm{v})$, using the glass electrode method (GL, pHS-3C, REX, Shanghai, China) according to the agricultural sector standard (NY/T1377-2007) of the People's Republic of China.

To ensure quality assurance and quality control (QA/QC), the precision and accuracy of all the methods were determined by analyzing the four standard reference materials (GSS-1, GSS-2, GSS-10, and GSS-11 soils) obtained from the Center of National Standard Reference Material of China for each batch of 12 samples analyzed. The analytical precision of all the methods, measured as the relative standard deviation (RSD), was generally below 0.05 , while the analytical accuracy, measured as the logarithmic deviation $(\Delta \log C)$ according to the Specification of Multi-purpose Regional Geochemical Survey recommended by CGS, was also generally below 0.05 . Pre-cleaned and acid-washed glassware were used for all analyses. All reagents and acids used were of analytical grade and were used without further purification. Distilled water was used to prepare the reagents. Reagent blanks and duplicate samples (about $16 \%$ of samples) were also used in the analytical program to detect contamination and assess the precision and accuracy of the analysis process. The recovery rates for the heavy metal and major elements in the standard reference materials (GSS-1, GSS-2, GSS-10 and GSS-11 soils) obtained from the Center of National Standard Reference Material of China were between 96.1 and 105\%. The analytical results showed no signs of contamination and revealed that the precision and accuracy of the analysis process, measured as logarithmic standard deviation and logarithmic deviation according to the Specification of 
Multi-purpose Regional Geochemical Survey recommended by CGS (2005), respectively, were both generally below $5 \%$. The detection limits for $\mathrm{As}, \mathrm{Hg}, \mathrm{Cu}, \mathrm{Pb}, \mathrm{Zn}, \mathrm{Cr}, \mathrm{MN}$, and $\mathrm{Cd}$ were $0.6,0.0004,1,2,2.5,10$, and $0.01 \mathrm{mg} / \mathrm{kg}$, respectively, while those for $\mathrm{Al}_{2} \mathrm{O}_{3}, \mathrm{CaO}, \mathrm{Fe}_{2} \mathrm{O}_{3}, \mathrm{MgO}$, $\mathrm{SiO}_{2}, \mathrm{~K}_{2} \mathrm{O}$, and $\mathrm{NaO}$ were $0.03 \%, 0.03 \%, 0.05 \%$, $0.03 \%, 0.1 \%, 0.05 \%$, and $0.1 \%$, respectively.

\section{Methodology}

\section{Descriptive Analysis}

Descriptive statistics, including the mean, range, standard deviation (SD), and coefficient of variations (CVs), were performed after analysis. The SD and CVs were incorporated to reflect the degree of dispersion distribution of different metals to indirectly indicate the activity of the selected elements in the examined environment [6]. In addition, the normal distribution of each variable was evaluated using the Kolmogorov-Smirnov test based on the raw data.

\section{Multivariate Statistical Analysis}

Pearson correlation coefficients were calculated to determine the relationships among metals and major elements to investigate elemental associations among the heavy metals and major elements in the soils.

Principal component analysis (PCA) is the most common multivariate statistical method used in environmental studies and is employed to extract a small number of latent factors for analyzing relationships among the observed variables [7, 19]. Like other multivariate statistical methods, PCA is useful in reducing data dimension while retaining important information and representing variables in a form that can be easily interpreted $[6,24]$. In this method, PCA results will vary considerably depending on whether the covariance or correlation matrix is used. In this study, PCA are calculated based on the correlation matrix because the concentrations of the heavy metals evaluated in this study vary by different orders of magnitude [6]. The first few Eigenvectors (or PCs) account for most of the data set variability [6]. To make the results of the present study more easily interpretable, varimax with Kaiser normalization was used as the rotation method to maximize the variances of the factor loadings across variables for each factor $[6,7]$. Moreover, prior to conducting PCA, Kaiser-MeyerOlkin (KMO) and Bartlett's sphericity tests were used to examine its validity [32]. The KMO and Bartlett's results for this study were 0.642 and $1432.871(\mathrm{p}<0.05)$, respectively, indicating that PCA may be useful for dimensionality reductions. In this study, all principal factors extracted from the variables were retained with the percentage of accumulated contribution of variances being larger than $80 \%$.

The raw data were standardized according to the $\mathrm{Z}$ score (whose mean and variance were set to zero and one, respectively) to minimize the effects of differences in measurement units or variance, and to render the data dimensionless [6].
Table 1. Threshold concentrations of each level of pollution for each metal in urban dust $(\mathrm{mg} / \mathrm{kg})$.

\begin{tabular}{|c|c|c|c|c|}
\hline & $X_{a}$ & $X_{c}$ & $X_{p}$ & $X_{b p}$ \\
\hline $\mathrm{As}$ & 15.00 & 25.00 & 30.00 & 50.00 \\
\hline $\mathrm{Cd}$ & 0.15 & 0.30 & 1.00 & 3.00 \\
\hline $\mathrm{Cr}$ & 90.00 & 200.00 & 300.00 & 600.00 \\
\hline $\mathrm{Cu}$ & 30.00 & 50.00 & 400.00 & 1000.00 \\
\hline $\mathrm{Hg}$ & 0.15 & 0.30 & 1.50 & 3.00 \\
\hline $\mathrm{Pb}$ & 35.00 & 250.00 & 500.00 & 1000.00 \\
\hline $\mathrm{Zn}$ & 100.00 & 200.00 & 500.00 & 1000.00 \\
\hline
\end{tabular}

\section{Methods of Heavy Metal Pollution Assessment}

To assess the degree of metal contamination, a revised pollution index for each metal and NIPI of the seven metals were attributed to each sampling site as proposed by [33]. The PI was defined as follows:

$$
\left\{\begin{array}{lc}
P I=C_{i} / X_{a} & C_{i} \leq X_{a} \\
P I=1+\left(C_{i}-X_{a}\right) /\left(X_{c}-X_{a}\right) & X_{a}<C_{i} \leq X_{c} \\
P I=2+\left(C_{i}-X_{c}\right) /\left(X_{p}-X_{c}\right) & X_{c}<C_{i} \leq X_{p} \\
P I=3+\left(C_{i}-X_{p}\right) /\left(X_{b p}-X_{p}\right) & X_{c}<C_{i} \leq X_{p} \\
P I=4+\left(C_{i}-X_{b p}\right) /\left(X_{b p}-X_{p}\right) & C_{i}>X_{b p}
\end{array}\right.
$$

...where $C_{i}$ is the measured concentration of each metal (As, $\mathrm{Cu}, \mathrm{Cr}, \mathrm{Cd}, \mathrm{Hg}, \mathrm{Pb}$, and $\mathrm{Zn}$ ) in this study, $X_{a}$ is the threshold concentration of the heavy metal enrichment, $X_{c}$ is the threshold concentration of the low level of pollution, $X_{p}$ is the threshold concentration of the high level of pollution, and $X_{b p}$ is the threshold concentration of serious pollution. The values of $X_{a}, X_{c}, X_{p}$, and $X_{b p}$, defined in Table 1, were the integration results of the document published by [6], the Environmental Quality Standard for Soils published by the National Environmental Protection Agency of China, and the Environmental Quality Standard for urban dust in Changchun suggested by [34].

The PI of each metal was classified as: non-pollution $(\mathrm{PI}<1)$, indicating that the level of metals was below the threshold concentration, but does not necessarily mean there was no pollution from anthropogenic sources or other enrichment over the background, low-level pollution $(1 \leq \mathrm{PI}<2)$, moderate-level pollution $(2 \leq \mathrm{PI}<3)$, high-level pollution $(3 \leq \mathrm{PI}<4)$, and extremely high-level pollution $(\mathrm{PI} \geq 4)$. The NIPI of the seven metals for each sampling site was defined as follows [33]:

$$
N I P I=\sqrt{\frac{P I^{2}{ }_{i \max }+P I^{2}{ }_{\text {iave }}}{2}}
$$

...where $P I_{\text {imax }}$ is the maximum PI value of each heavy metal and $P I_{\text {iave }}$ is the average PI value of each heavy metal. 
Table 2. Heavy metal ( $\mathrm{mg} / \mathrm{kg})$ and main element (\%) concentrations of urban dusts in Changchun.

\begin{tabular}{|c|c|c|c|c|c|c|c|c|}
\hline & As & $\mathrm{Cd}$ & $\mathrm{Cr}$ & $\mathrm{Cu}$ & $\mathrm{Hg}$ & $\mathrm{Pb}$ & $\mathrm{Zn}$ & $\mathrm{Mn}$ \\
\hline Minimum & 8.95 & 0.212 & 66.11 & 35.71 & 0.038 & 40.3 & 164 & 547 \\
\hline Maximum & 114.4 & 7.379 & 175.54 & 636.95 & 6.656 & 523.6 & 2533 & 1326 \\
\hline Mean & $23.26^{\mathrm{a}}$ & $0.624^{\mathrm{a}}$ & $95.98^{b}$ & $68.41^{\mathrm{a}}$ & $0.239^{\mathrm{a}}$ & $93.6^{\mathrm{a}}$ & $465.35^{\mathrm{b}}$ & $692^{\mathrm{a}}$ \\
\hline Standard deviation & 10.37 & 0.84 & 18.19 & 45.05 & 0.54 & 54.43 & 295.96 & 75.22 \\
\hline Variation coefficient & 0.45 & 1.35 & 0.19 & $0.66^{\mathrm{c}}$ & $2.26^{\mathrm{c}}$ & $0.58^{\mathrm{c}}$ & 0.64 & $0.11^{\mathrm{c}}$ \\
\hline Skewness & $1.09^{\mathrm{c}}$ & $1.43^{\mathrm{c}}$ & 1.95 & $1.94^{\mathrm{c}}$ & $0.96^{\mathrm{c}}$ & $1.24^{\mathrm{c}}$ & 3.84 & 1.85 \\
\hline Kurtosis & $5.696^{c}$ & $3.127^{\mathrm{c}}$ & 4.865 & 8.981 & 1.880 & 3.679 & 18.59 & $9.316^{\mathrm{c}}$ \\
\hline $\mathrm{TD}^{\mathrm{d}}$ & $\mathrm{LgN}$ & $\mathrm{LgN}$ & Skewed & $\mathrm{LgN}$ & $\mathrm{LgN}$ & $\mathrm{LgN}$ & Skewed & $\operatorname{LgN}$ \\
\hline Changchun topsoil $\mathrm{MV}^{\mathrm{e}}$ & 12.5 & 0.132 & 66.0 & 29.4 & 0.118 & 35.4 & 90.0 & 743 \\
\hline Atmospheric dry and wet deposition ${ }^{\mathrm{f}}$ & 38.9 & 2.241 & 92.3 & 76.17 & 0.27 & 115.2 & 462 & - \\
\hline Changchun $\mathrm{BK}^{\mathrm{g}}$ & 10.590 & 0.09 & 54.17 & 18.9 & 0.04 & 19.06 & 59.860 & - \\
\hline 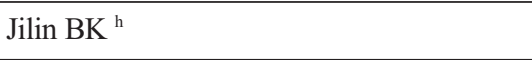 & 11.60 & 0.09 & 42.40 & 14.8 & 0.03 & 14.96 & 45.950 & 605 \\
\hline Jilin $\mathrm{MV}^{\mathrm{i}}$ & 8.82 & 0.11 & 51.4 & 18.0 & 0.03 & 24.4 & 57.22 & 674 \\
\hline Residential/recreational intervention limits & 20 & 2 & 150 & 120 & 1 & 100 & 150 & - \\
\hline \multirow[t]{2}{*}{ Industrial/commercial intervention limits } & 50 & 15 & 800 & 600 & 5 & 1000 & 1500 & - \\
\hline & $\mathrm{Al}_{2} \mathrm{O}_{3}$ & $\mathrm{CaO}$ & $\mathrm{Fe}_{2} \mathrm{O}_{3}$ & $\mathrm{~K}_{2} \mathrm{O}$ & $\mathrm{MgO}$ & $\mathrm{Na}_{2} \mathrm{O}$ & $\mathrm{SiO}_{2}$ & $\mathrm{~S}$ \\
\hline Min & 9.56 & 2.82 & 3.71 & 1.38 & 1.26 & 0.98 & 36.61 & 0.06 \\
\hline Max & 16.01 & 19.60 & 8.46 & 3.51 & 4.27 & 3.47 & 60.95 & 1.92 \\
\hline Mean & $13.17^{b}$ & $5.06^{\mathrm{a}}$ & $4.53^{\mathrm{a}}$ & $2.31^{\mathrm{b}}$ & 1.76 & 1.85 & $54.35^{b}$ & 0.26 \\
\hline Standard deviation & 0.64 & 1.59 & 0.55 & 0.19 & 0.30 & 0.25 & 2.83 & 0.22 \\
\hline Variation coefficient & 0.05 & 0.31 & 0.12 & 0.08 & 0.17 & 0.14 & 0.05 & 0.85 \\
\hline Skewness & -0.63 & $1.66^{\mathrm{c}}$ & $1.80^{\mathrm{c}}$ & 1.11 & $1.43^{\mathrm{c}}$ & $0.15^{c}$ & -1.85 & $0.33^{\mathrm{c}}$ \\
\hline Kurtosis & 5.924 & $7.784^{c}$ & $6.668^{c}$ & 11.693 & $5.882^{c}$ & $6.840^{c}$ & 8.126 & $0.912^{\mathrm{c}}$ \\
\hline $\mathrm{TD}^{\mathrm{d}}$ & Normal & $\mathrm{LgN}$ & $\mathrm{LgN}$ & Skewed & $\mathrm{LgN}$ & $\mathrm{LgN}$ & Normal & $\mathrm{LgN}$ \\
\hline Changchun topsoil MV & $14.05^{b}$ & $1.74^{\mathrm{b}}$ & $4.56^{\mathrm{a}}$ & $2.61^{\mathrm{b}}$ & $1.27^{\mathrm{b}}$ & $1.77^{\mathrm{b}}$ & $64.52^{\mathrm{b}}$ & - \\
\hline Jilin $\mathrm{BK}^{\mathrm{h}}$ & $\mathrm{ND}$ & 1.010 & ND & 1.940 & ND & 1.540 & $\mathrm{ND}$ & - \\
\hline Jilin $\mathrm{MV}^{\mathrm{i}}$ & 12.83 & 1.28 & 3.92 & 2.59 & 1.18 & 1.91 & 66.58 & - \\
\hline
\end{tabular}

${ }^{\mathrm{a}}$ Geometrical mean, ${ }^{\mathrm{b}}$ Arithmetical mean, ${ }^{\mathrm{c}}$ Values were obtained using a lognormal transformation, ${ }^{\mathrm{d}}$ Type of distribution, ${ }^{\mathrm{e}}$ Average values of the topsoil in Changchun, A layer $(0 \sim 20 \mathrm{~cm})$, total 352 samples [30], ${ }^{\mathrm{f}}$ Average values of atmospheric dry and wet deposition in Changchun [27], ${ }^{\mathrm{g}}$ Background values of the soil in Changchun [36], ${ }^{\mathrm{h}}$ Background values of the soil in Jilin Province [36], ${ }^{\mathrm{i}}$ Average values of the soil in Jilin Province, A layer $(0 \sim 20 \mathrm{~cm})$, about 8,000 samples,

ND - No data, Normal - normal distribution, LgN - lognormal distribution

The NIPI was classified as: non-pollution (NIPI $\leq 0.7)$, warning line of pollution $(0.7<\mathrm{NIPI} \leq 1)$, low level of pollution $(1<\mathrm{NIPI} \leq 2)$, moderate level of pollution $(2<\mathrm{NIPI} \leq 3)$, and high level of pollution (NIPI>3) [33].

\section{Results and Discussion}

\section{Concentrations of Heavy Metals and Major Elements}

The concentrations of heavy metals and major elements in the urban dusts of Changchun and their descriptive sta- tistical results are listed in Table 2. The results of the Kolmogorov-Smirnov test $(\mathrm{p}<0.01)$ showed that $\mathrm{Al}_{2} \mathrm{O}_{3}$ and $\mathrm{SiO}_{2}$ concentrations fit a normal distribution (K-S probability were 0.32 and 0.04 , respectively), while the $\mathrm{As}, \mathrm{Cd}, \mathrm{Cr}$, $\mathrm{Cu}, \mathrm{Hg}, \mathrm{Pb}, \mathrm{Zn}, \mathrm{Mn}, \mathrm{CaO}, \mathrm{MgO}, \mathrm{Na}_{2} \mathrm{O}, \mathrm{S}, \mathrm{Fe}_{2} \mathrm{O}_{3}$, and $\mathrm{K}_{2} \mathrm{O}$ were skewed. However, the $\mathrm{As}, \mathrm{Cd}, \mathrm{Cu}, \mathrm{Hg}, \mathrm{Pb}, \mathrm{Mn}, \mathrm{CaO}$, $\mathrm{MgO}, \mathrm{Na}_{2} \mathrm{O}, \mathrm{S}$, and $\mathrm{Fe}_{2} \mathrm{O}_{3}$ levels were found to almost fit a normal distribution after the data were naturally logarithmically transformed (K-S probability were $0.48,0.02,0.11$, $0.15,0.03,0.08,0.14,0.09,0.04,0.58$, and 0.5 , respectively). There is an extremely significant difference for $\mathrm{Cr}, \mathrm{Zn}$, and $\mathrm{K}_{2} \mathrm{O}$, which is observed to fit a skewed distribution 
Table 3. Comparison of mean concentrations $(\mathrm{mg} / \mathrm{kg})$ of metal in urban dusts from different cities $(\mathrm{mg} / \mathrm{kg})$.

\begin{tabular}{|l|c|c|c|c|c|c|c|c|c|}
\hline \multicolumn{1}{|c|}{ City } & $\mathrm{As}$ & $\mathrm{Cd}$ & $\mathrm{Cr}$ & $\mathrm{Cu}$ & $\mathrm{Hg}$ & $\mathrm{Pb}$ & $\mathrm{Zn}$ & height & References \\
\hline Changchun (N=232) & 23.26 & 0.62 & 95.98 & 68.41 & 0.24 & 93.6 & 465.35 & Urban dusts & This study \\
\hline Nanjing (N=35) & 13.40 & 1.10 & 126.00 & 123.00 & 0.12 & 103.0 & 394.00 & Street dusts & {$[4]$} \\
\hline Xi'an (N=65) & 10.62 & - & 167.28 & 94.98 & 0.64 & 230.5 & 401.46 & Street dusts & {$[6]$} \\
\hline Zhuzhou (N=55) & 89.00 & 41.40 & 125.00 & 139.00 & 0.92 & 956.0 & 2379.00 & Street dusts & {$[9]$} \\
\hline Greater Toronto (N=42) & - & 0.51 & 197.90 & 162.20 & - & 182.8 & 232.80 & Street dusts & {$[11]$} \\
\hline Shanghai (N=273) & - & 1.23 & 159.30 & 196.80 & - & 294.9 & 733.80 & Street dusts & {$[16]$} \\
\hline Xi'an (N=92) & 28.50 & - & - & 102.70 & - & 266.3 & 798.00 & Street dusts & {$[20]$} \\
\hline Chengdu (N=318) & 41.90 & 4.33 & 112.00 & 240.00 & 0.54 & 372.0 & 1078.00 & $1.5 \mathrm{~m}$ height & {$[40]$} \\
\hline Birmingham (N=100) & - & 1.62 & - & 466.90 & - & 47.1 & 385.70 & Street dusts & {$[41]$} \\
\hline Beijing (N=50) & - & 0.64 & 69.33 & 72.13 & - & 201.8 & 219.20 & Street dusts & {$[42]$} \\
\hline Baoji (N=38) & 19.80 & - & 126.70 & 123.20 & 1.10 & 433.2 & 715.30 & Street dusts & {$[43]$} \\
\hline Urmqi (N=169) & - & 1.17 & 54.28 & 94.54 & - & 53.5 & 294.47 & Street dusts & {$[44]$} \\
\hline
\end{tabular}

“_" - No data, N - Number of samples.

even though the data were naturally logarithmically transformed. The mean values were adopted for analyses when the heavy metal concentrations had normal distributions. The geometric mean values were used when the heavy metal concentrations had lognormal distributions. Each heavy metal showed a wide variety of concentration, which is typical in urban dusts and may imply that there are some hot-spots in Changchun that have been polluted by heavy metal pollution in urban dust [11]. However, most of the major elements showed a relatively narrow interval, except for $\mathrm{CaO}$ and $\mathrm{S}$. The relatively wide range of $\mathrm{CaO}$ may have been caused by the excessive input of building materials into urban dusts, such as cement and calcareousness [29]. When compared with the background values of the topsoil in the Changchun region, the mean concentrations of all elements were significantly elevated, and these values were also significantly higher than the background values of Jilin $[35,36]$. In addition, it should be noted that the heavy metal and $\mathrm{CaO}$ concentrations in urban dusts of Changchun are generally higher than those of the mean concentrations in soils from Jilin Province. The mean concentrations of $\mathrm{Al}_{2} \mathrm{O}_{3}, \mathrm{Fe}_{2} \mathrm{O}_{3}, \mathrm{~K}_{2} \mathrm{O}, \mathrm{MgO}, \mathrm{Na}_{2} \mathrm{O}$, and $\mathrm{SiO}_{2}$ were comparable with the mean concentrations in soils from Jilin Province and in topsoil from Changchun. Compared with the mean concentrations of heavy metals in atmospheric dry and wet depositions, the mean concentration of heavy metals in urban dust was generally low, except for $\mathrm{Cr}$. However, it is much higher than those of the mean concentrations in topsoil in Changchun [30]. Taken together, these findings may imply that anthropogenic input is responsible for the presence of these elements in urban dust.

Based on the variation coefficients (VCs), the examined elements can be classified into three groups: $\mathrm{Cr}, \mathrm{Mn}, \mathrm{Al}_{2} \mathrm{O}_{3}$, $\mathrm{K}_{2} \mathrm{O}, \mathrm{Fe}_{2} \mathrm{O}_{3}, \mathrm{MgO}, \mathrm{Na}_{2} \mathrm{O}$, and $\mathrm{SiO}_{2}$, which had $\mathrm{VC}$ values lower than 0.2; $\mathrm{Cd}$ and $\mathrm{Hg}$, which had $\mathrm{VC}$ values higher than 1.0; and all other elements with $\mathrm{VC}$ values between 0.2 and 1.0. We would expect those elements dominated by a natural source to have low VCs, while the VCs of elements influenced by anthropogenic sources would be expected to be quite high. This is the case for urban dusts, for they have undergone erosion and aeolian transport before ultimate deposition, and have therefore been fully mixed [6].

The mean values of most heavy metals in the analyzed urban dusts in Changchun are generally much lower than those reported for samples from some large and/or industrialized cities (Chengdu, Nanjing, Shanghai, Xi'an, Hong Kong, Zhuzhou, Baoij, Toronto, Birmingham, etc.), but are generally higher than those measured in smaller, undeveloped cities (i.e. Urmqi), particularly $\mathrm{Cr}, \mathrm{Pb}$, and $\mathrm{Zn}$ (Table 3). Although Changchun is one of the oldest industrial cities in China, the industrial history of Changchun is shorter than that of other industrialized cities, and pollution occurred at a later stage in these areas. Therefore, although near-surface urban dust from a height of $1.5 \mathrm{~m}$ was collected in this study, and samples were collected from street surfaces and from areas with different background environments in other studies (Table 3), the relatively lower concentrations of heavy metals in the urban dust in Changchun could be the result of a shorter accumulation time and lower rate. Certainly, the relatively high sampling height of this study may also influence the concentration levels. Particularly, it should also be noted that the concentrations of $\mathrm{Pb}$ in the analyzed samples are also significantly lower than those reported in studies of metropolitan areas in cities such as Xi'an, Chengdu, Beijing, London, Shanghai, Zhuzhou, and Baoji; these samples are comparable to those measured in some other parts of the world (i.e. Nanjing and Hong Kong). Meanwhile, the concentrations of $\mathrm{Zn}$ in the analyzed samples are also significantly lower than those in Chengdu, Hong Kong, and Zhuzhou, and are comparable to 
Table 4. Pearson's correlation matrix for metal concentrations.

\begin{tabular}{|c|c|c|c|c|c|c|c|}
\hline & $\mathrm{As}$ & $\mathrm{Cd}$ & $\mathrm{Cr}$ & $\mathrm{Cu}$ & $\mathrm{Hg}$ & $\mathrm{Pb}$ & $\mathrm{Zn}$ \\
\hline $\mathrm{As}$ & 1.000 & & & & & & \\
\hline $\mathrm{Cd}$ & 0.081 & 1.000 & & & & & \\
\hline $\mathrm{Cr}$ & -0.094 & 0.085 & 1.000 & & & & \\
\hline $\mathrm{Cu}$ & 0.012 & 0.065 & $0.205^{* *}$ & 1.000 & & & \\
\hline $\mathrm{Hg}$ & 0.020 & -0.063 & -0.053 & 0.054 & 1.000 & & \\
\hline $\mathrm{Pb}$ & $0.205^{* *}$ & $0.137^{*}$ & $0.281^{* *}$ & $0.427^{* *}$ & -0.005 & 1.000 & \\
\hline $\mathrm{Zn}$ & 0.072 & 0.068 & 0.066 & $0.170^{* *}$ & -0.027 & $0.130^{*}$ & 1.000 \\
\hline
\end{tabular}

*Correlation is significant at the 0.05 level (2-tailed).

**Correlation is significant at the 0.01 level (2-tailed).

Table 5. Matrix of the principal component analysis loadings of metals and major elements of urban dusts in Changchun city

\begin{tabular}{|c|c|c|c|c|c|c|c|c|}
\hline \multirow[b]{2}{*}{ Variable } & \multicolumn{7}{|c|}{ Principal loading factors } & \multirow[b]{2}{*}{ Communalities } \\
\hline & $\begin{array}{c}\text { PC1 } \\
(18.213 \%)\end{array}$ & $\begin{array}{c}\text { PC2 } \\
(14.39 \%)\end{array}$ & $\begin{array}{c}\text { PC3 } \\
(11.20 \%)\end{array}$ & $\begin{array}{c}\text { PC4 } \\
(10.01 \%)\end{array}$ & $\begin{array}{c}\text { PC5 } \\
(9.44 \%)\end{array}$ & $\begin{array}{c}\text { PC6 } \\
(9.17 \%)\end{array}$ & $\begin{array}{c}\text { PC7 } \\
(9.12 \%)\end{array}$ & \\
\hline As & -0.180 & 0.171 & 0.849 & -0.177 & -0.058 & -0.025 & 0.074 & 0.823 \\
\hline $\mathrm{Cd}$ & 0.088 & 0.064 & 0.042 & 0.007 & 0.034 & -0.026 & 0.988 & 0.992 \\
\hline $\mathrm{Cr}$ & 0.688 & 0.402 & -0.030 & 0.119 & -0.075 & -0.031 & -0.020 & 0.657 \\
\hline $\mathrm{Cu}$ & 0.116 & 0.752 & -0.075 & 0.125 & 0.195 & 0.106 & -0.016 & 0.650 \\
\hline $\mathrm{Pb}$ & -0.025 & 0.867 & 0.125 & -0.136 & -0.023 & -0.062 & 0.097 & 0.800 \\
\hline $\mathrm{Zn}$ & 0.016 & 0.130 & 0.058 & -0.021 & 0.960 & -0.026 & 0.034 & 0.945 \\
\hline $\mathrm{Hg}$ & -0.080 & 0.033 & 0.012 & 0.005 & -0.024 & 0.988 & -0.026 & 0.984 \\
\hline $\mathrm{CaO}$ & -0.021 & 0.014 & -0.006 & 0.946 & -0.023 & 0.002 & 0.008 & 0.896 \\
\hline $\mathrm{Fe}_{2} \mathrm{O}_{3}$ & 0.788 & 0.035 & 0.083 & -0.171 & 0.141 & -0.106 & 0.051 & 0.691 \\
\hline $\mathrm{MgO}$ & 0.293 & -0.191 & 0.688 & 0.301 & 0.213 & 0.059 & -0.033 & 0.737 \\
\hline Mn & 0.873 & -0.121 & -0.062 & 0.079 & -0.041 & 0.021 & 0.075 & 0.795 \\
\hline
\end{tabular}

${ }^{a}$ Extraction Method: Principal Component Analysis. Rotation Method: Varimax with Kaiser Normalization. Rotation converged in 7 iterations.

The percentage in brackets is the explained contribution of principal components to the total variance.

The boldfaced numbers are the dominant elements in different PCs.

those measured in London, Birmingham, and Xi'an. Because each city has its own characteristic combination of elemental compositions, the observed similarities, as well as variations, may not reflect actual natural and anthropogenic diversities among the different urban settings. Therefore, there is an immediate need to establish a standard procedure to represent and analyze urban samples.

\section{Correlation Coefficient Analysis}

To a certain extent, Pearson's correlation coefficient can be used to measure the degree of correlation between the metal data and can provide suggestive information regarding heavy metal sources and pathways $[6,18]$. The results of Pearson's correlation coefficients of heavy metals in urban dusts in Changchun are summarized in Table 4 . $\mathrm{Pb}$ were significantly positively correlated to $\mathrm{As}, \mathrm{Cd}, \mathrm{Cr}, \mathrm{Cu}$, and $\mathrm{Zn}$.
Meanwhile, $\mathrm{Cu}$ also displayed a significant positive correlation with $\mathrm{Cr}$ and $\mathrm{Zn}$, indicating that the general contamination sources for these metals were primarily traffic and industrial activities [18]. Furthermore, it should be noted that $\mathrm{Hg}$ was not significantly correlated with all other heavy metals considered, indicating that there are some unique sources of $\mathrm{Hg}$ that are currently unknown.

\section{Multivariate Statistical Analysis}

In the present study, PCA was applied to assist in the identification of the sources of pollutants [7, 22]. The results of PCA of the metal concentrations in the urban soils are shown in Table 5. The first seven principal components were considered during the PCA, accounting for over $81.54 \%$ of the total variance, reflecting the majority of the data [7]. 
Table 6. The average concentrations of metals in gasoline, diesel oil, and tire and vehicle exhaust in Changchun.

\begin{tabular}{|l|c|c|c|c|c|}
\hline & $\begin{array}{c}\text { Gasoline } \\
(\mathrm{g} / \mathrm{L})\end{array}$ & $\begin{array}{c}\text { Diesel oil } \\
(\mathrm{mg} / \mathrm{kg})\end{array}$ & $\begin{array}{c}\text { Tire dust } \\
(\mathrm{mg} / \mathrm{kg})\end{array}$ & $\begin{array}{c}\text { Vehicle exhaust (gasoline) } \\
(\mathrm{mg} / \mathrm{kg})\end{array}$ & $\begin{array}{c}\text { Vehicle exhaust (diesel oil) } \\
(\mathrm{mg} / \mathrm{kg})\end{array}$ \\
\hline $\mathrm{Cu}$ & 0.002 & 2.430 & 16.480 & 255.0 & 109 \\
\hline $\mathrm{Pb}$ & 2.11 & 0.130 & 12.7 & 440.0 & 45.75 \\
\hline $\mathrm{Zn}$ & No data & No data & No data & 1900 & 1898 \\
\hline References & {$[29]$} & {$[29]$} & {$[29]$} & {$[30]$} & {$[37]$} \\
\hline
\end{tabular}

PC1 was dominated by $\mathrm{Cr}, \mathrm{Fe}_{2} \mathrm{O}_{3}$, and $\mathrm{Mn}$, accounting for $18.21 \%$ of the total variance. In general, $\mathrm{Fe}_{2} \mathrm{O}_{3}$ and $\mathrm{Mn}$ represented a natural geochemical association of major rock-forming elements in soils, which may reflect a natural origin from weathered soil dust [7, 19]. The first principal component accounted for most of the variability in the data, and each succeeding component accounted for a reduced percentage of the remaining variability. Hence, fugitive dust from soil dust was shown to have a dominant influence on urban dusts in Changchun, and PC1 may be summarized as a 'natural' factor. Even some previous studies reported that $\mathrm{Cr}$ might originate from industrial discharges or traffic sources $[7,19]$. The relatively low mean concentration of $\mathrm{Cr}(95.98 \mathrm{mg} / \mathrm{kg})$ can be compared with the mean concentrations in Changchun topsoil $(66.0 \mathrm{mg} / \mathrm{kg})$ and may further support the conclusion that $\mathrm{Cr}$ may still be controlled by natural sources. However, it should be noted that $\mathrm{Cr}$ was positively correlated with $\mathrm{Cu}$ and $\mathrm{Pb}$ upon correlation coefficient and PCA analysis (PC2), suggesting less significant anthropogenic origins such as traffic emissions.

PC2 was dominated by $\mathrm{Cu}$ and $\mathrm{Pb}$. The strong relationship between these two elements may reflect anthropogenic contamination of urban dusts. In fact, this factor source may usually be explained by contributions mainly from vehicle emissions, especially cars that consume lead gasoline [19]. Over the past 50 years, vehicle emissions have been considered to be the principal source of $\mathrm{Pb}$ in soil and urban dusts. This has been verified by many related studies [7, 19]. Previous studies showed that even though the use of lead petroleum has been banned in Changchun since 1998, and the content of $\mathrm{Pb}$ in the troposphere has decreased [37]. The concentration of $\mathrm{Pb}$ in urban soils still reflects the significant degree of historical $\mathrm{Pb}$ contamination and the long half-life of $\mathrm{Pb}$ in soils, which is one of the sources of urban dust [37]. The mean concentration of $\mathrm{Pb}$ in urban dusts was $93.6 \mathrm{mg} / \mathrm{kg}$ in the present study, while it was found to be $255.0 \mathrm{mg} / \mathrm{kg}$ in the car emission dust of 2005 [29]. In addition, $\mathrm{Cu}$ was also present in high concentrations in the automotive exhaust in Changchun (Table 6). Copper alloy is a material used in mechanical parts due to its desirable qualities such as corrosive resistance and strength. Copper is also used in Cu-brass automotive radiators and brakes due to its high corrosive resistance and high thermal conductivity. However, the deterioration of the mechanical parts in vehicles over time will result in $\mathrm{Cu}$ being emitted into the surrounding environment (Adachi and Tainosho documents that the $\mathrm{Cu}$ content in brake dust is $1.2 \%$ ) [23].
PC3 is loaded primarily by As and $\mathrm{MgO}$ and accounts for $11.20 \%$ of the total variance. The source for this factor is soil dust. $\mathrm{MgO}$ generally represents a natural geochemical association of major rock-forming elements in soils and may reflect a natural origin from parent rocks. The strong relationship between $\mathrm{As}$ and $\mathrm{MgO}$ indicates that $\mathrm{As}$ in urban dusts may primarily originate from natural sources, and the effect of some other anthropogenic sources, such as traffic emissions, industrial discharges, coal combustion, etc., could be negligible. Based on these findings, PC3 may be labeled as a 'natural' factor.

$\mathrm{CaO}, \mathrm{Zn}, \mathrm{Hg}$, and $\mathrm{Cd}$ were unequivocally isolated in the fourth, fifth, sixth, and seventh components (PC4, PC5, PC6, and PC7), respectively. The PCA analysis showed that $\mathrm{CaO}$ displayed a relatively weak association with most of the other elements; but it did show a relatively significant correlation with $\mathrm{MgO}$. These features may indicate that $\mathrm{CaO}$ has some unique sources. In fact, excessive input of building materials into the urban environment may be the reason following the analysis mentioned above. Meanwhile, the content of $\mathrm{Ca}$ in building dust was $12.15 \%$ in Changchun [30]. However, the origin of $\mathrm{CaO}$ in urban dust in Changchun should be confirmed by further studies. $\mathrm{Zn}$ also displayed a relatively weak association with most of the other elements. Some studies imply that traffic activities may be a significant contribution to $\mathrm{Zn}[6,19]$, especially the mechanical abrasion of vehicles. Zinc, added as an additive (mainly as antioxidants, e.g., Zinc carboxylate complexes and zinc sulphonates) during the vulcanizing process, comprises from $0.4 \%$ to $4.3 \%$ of the resulting tire tread, and is a vital and significant source of $\mathrm{Zn}$ pollution in dusts [23]. Therefore, the origin of $\mathrm{Zn}$ may mainly result from anthropogenic sources, especially traffic dust. In addition, spatial distribution of high values of $\mathrm{Zn}$ are always near heavy traffic routes, and do show some relationship to traffic activities [34]; this feature is in agreement with the literature published by Han et al. [6].

The sixth group of elements only consists of $\mathrm{Hg}$ (PC6). Elements such as $\mathrm{Hg}$ are commonly considered to be indicators of coal combustion and waste incineration [38]. The analysis of six common coal combustion fly ash samples collected from Changchun revealed that the mean concentrations of $\mathrm{Hg}$ in the coal combustion fly ash were 3.492 $\mathrm{mg} / \mathrm{kg}$. In 2012, approximately 24.7 million tons of coal were consumed in this city. Meanwhile, it should be pointed out that, besides the coal combustion emission, $\mathrm{Hg}$ can also be emitted from the smelting of sulfide mineral. 
Table 7. Statistical results of pollution index (PI) of heavy metals in Changchun urban dusts.

\begin{tabular}{|c|c|c|c|c|c|c|c|c|}
\hline \multirow{2}{*}{} & \multicolumn{3}{|c|}{ PI } & \multicolumn{5}{c|}{ Number of samples } \\
\cline { 2 - 10 } & Min & Max & Mean & Non-pollution & Low & Middle & High & Extremely high \\
\hline $\mathrm{As}$ & 0.59 & 8.22 & 2.03 & 13 & 131 & 52 & 32 & 4 \\
\hline $\mathrm{Hg}$ & 0.25 & 7.44 & 1.53 & 64 & 92 & 70 & 5 & 1 \\
\hline $\mathrm{Cr}$ & 0.73 & 1.78 & 1.05 & 99 & 133 & 0 & 0 & 0 \\
\hline $\mathrm{Cu}$ & 1.29 & 3.39 & 2.04 & 0 & 26 & 205 & 1 & 0 \\
\hline $\mathrm{Pb}$ & 1.02 & 3.05 & 1.31 & 0 & 226 & 5 & 1 & 0 \\
\hline $\mathrm{Zn}$ & 1.64 & 8.07 & 2.82 & 0 & 4 & 169 & 49 & 10 \\
\hline $\mathrm{Cd}$ & 1.41 & 7.19 & 2.56 & 0 & 7 & 196 & 22 & 7 \\
\hline
\end{tabular}

The atmospheric depositions of $\mathrm{Hg}$ were $0.030 \mathrm{mg} / \mathrm{m}^{2} / \mathrm{a}$, and the contribution of coal burning was significant [27]. In addition, spatial distribution of high values of $\mathrm{Hg}$ do show some relationship to industrial activities such as waste incineration, metal refining and manufacturing, papermaking, coal-fired power plants, and the chemical industry [34]; this feature is in agreement with the literature [39].

$\mathrm{Cd}$ was unequivocally isolated in the seventh component (PC7) of Changchun urban dust and showed a weak association with other elements. This may indicate that it had some unique sources. In fact, industrial discharge may contribute significantly to the accumulation of $\mathrm{Cd}$ in urban dusts [19]. The spatial distribution of $\mathrm{Cd}$ also confirmed these inferences, as documented previously by literature [34] in more detail.

Although the results of the present study provide preliminary conclusions regarding the origin of each metal, further studies are necessary to gain a better understanding of pollution sources based on the spatial distribution of each metal.

\section{Metal Pollution Assessment}

The minimum, maximum, and mean values of PI for each element are shown in Table 7. The mean PI values were generally low, indicating that there was no serious dust pollution. However, the PI values varied greatly among metals and among different sample locations. The PI values for $\mathrm{Cr}$ in urban dust ranged from 0.73 to 1.78 , indicating that urban dust in Changchun was uncontaminated to low-level contaminated. Indeed, most of the samples (133 samples) had low PI values for $\mathrm{Cr}$, and the other 99 samples had PI values indicating non-pollution. These findings suggest that the concentrations of $\mathrm{Cr}$ in urban dusts were comparable to the first grade threshold value established by the Environmental Quality Standard for Soils and suggested by literature [34]; also, there was no obvious pollution of $\mathrm{Cr}$ in the urban dust. This finding may further support the conclusion that $\mathrm{Cr}$ may still be controlled by natural sources. The PI values for $\mathrm{Cu}$ and $\mathrm{Pb}$ in urban dust ranged from 1.29 to 3.39 and 1.02 to 3.05 , respectively. Most of the samples (231 samples) had low or moderate PI values for $\mathrm{Cu}$ and $\mathrm{Pb}$. However, only 1 sample had PI values indicating heavy pollution. Thus, the dust quality of Changchun has deteriorated relative to natural conditions, and it is likely that many of the urban dusts in Changchun have been polluted with low or moderate levels of $\mathrm{Cu}$ and $\mathrm{Pb}$. Meanwhile, the mean value of the PI value for $\mathrm{Cu}$ was 2.04 , displaying a moderate level of pollution; the $\mathrm{Pb}$ was a low level of pollution (mean PI value for $\mathrm{Pb}$ was 1.31). Nearly $76.93 \%$ of the study area displayed a moderate level of pollution for $\mathrm{Cu}$.

The PI values of $\mathrm{Cd}, \mathrm{Zn}, \mathrm{As}$, and $\mathrm{Hg}$ in urban dust varied greatly, ranging from 1.41 to $7.19,1.64$ to $8.07,0.59$ to 8.22 , and 0.25 to 7.44 , respectively, implying that some sample locations were seriously contaminated. Furthermore, high PI values (higher than 2) were observed in $97.83 \%$ of the samples for $\mathrm{Cd}, 98.76 .3 \%$ for $\mathrm{Zn}, 37.93 \%$ for As, and $32.76 \%$ for $\mathrm{Hg}$. These data indicate that $\mathrm{Cd}, \mathrm{Zn}, \mathrm{As}$, and $\mathrm{Hg}$ pollution, particularly $\mathrm{Cd}, \mathrm{Zn}$ and As pollution, is relatively serious in Changchun topsoil when compared with other elements. The mean PI values of $\mathrm{Cd}, \mathrm{Zn}$ and As were 2.56, 2.82 , and 2.03, respectively.

There was no significant difference for PI values among different districts (Fig. 3). However, the mean PI values for As and $\mathrm{Hg}$ in urban dust were generally higher in Nanguan and Chaoyang. Nanguan is an old urban area with a dense population, heavy traffic, and many industrial activities when compared with other districts, indicating the presence of relatively serious heavy metal pollution in Nanguan District. Chaoyang District is the downtown area with a dense population and has the highest traffic density. The reason for the relatively high PI values in Nanguan and Chaoyang districts should be considered and further studies should be conducted in the future.

The NIPIs of all samples varied from 1.76 to 6.12 , with an average of 2.63, indicating a moderate level of pollution of local urban dusts (Table 8). Assessment of the data shows that there were only 19 samples (about $8.19 \%$ of all samples) with an NIPI value below 2, while approximately $80.60 \%$ of all samples (187 samples) had a NIPI value between 2 and 3, indicating high levels of pollution of local urban dusts, only $1.72 \%$ of all samples (4 samples) had a NIPI value between 3 and 4 and $9.48 \%$ of all samples 
Table 8. Statistical results of Nemerow integrated pollution index (NIPI) of heavy metals in urban dusts of Changchun.

\begin{tabular}{|c|c|c|c|c|c|c|c|}
\hline \multicolumn{3}{|c|}{ NIPI } & \multicolumn{5}{|c|}{ Number of samples } \\
\hline Min & Max & Mean & $\begin{array}{c}\text { Non-pollution } \\
(\text { NIPI } \leq 0.7)\end{array}$ & $\begin{array}{c}\text { Warning line pollution } \\
(0.7<\text { NIPI } \leq 1)\end{array}$ & $\begin{array}{c}\text { Low level pollution } \\
(1<\text { NIPI } \leq 2)\end{array}$ & $\begin{array}{c}\text { Middle level pollution } \\
(2<\text { NIPI } \leq 3)\end{array}$ & $\begin{array}{c}\text { High level } \\
\text { pollution NIPI } \geq 3\end{array}$ \\
\hline 1.76 & 6.12 & 2.63 & 0 & 0 & 19 & 187 & 26 \\
\hline
\end{tabular}

(22 samples) had an NIPI>4, indicating a high level of pollution of local urban dusts. Overall, these findings suggest that the dust of Changchun has been polluted by anthropogenic emissions. Fig. 4 shows the spatial distributions of NIPIs in Changchun. Dust sample sites with extremely high levels of pollution (NIPI $>3$ ) were primarily located in areas close to facilities for smelting, the chemical production, tanneries, etc.. Meanwhile, the hot-spot areas are distributed relatively separately. Therefore, metals present in the emissions from industrial facilities may significantly affect urban dust in these sites. Although most of these facilities have been relocated in recent years, the historical accumulation of metals should not be ignored.

\section{Conclusions}

The present study examined the content of metals in the urban dusts in Changchun in northeast China. Major elements in urban dusts were also analyzed, including $\mathrm{Mn}$, $\mathrm{Al}_{2} \mathrm{O}_{3}, \mathrm{CaO}, \mathrm{Fe}_{2} \mathrm{O}_{3}, \mathrm{MgO}, \mathrm{SiO}_{2}, \mathrm{~K}_{2} \mathrm{O}$, and $\mathrm{NaO}$. Urban dusts in Changchun were found to have elevated concentrations of a number of heavy metals, including $\mathrm{Cu}, \mathrm{Pb}, \mathrm{Hg}, \mathrm{As}, \mathrm{Cd}, \mathrm{Cr}$, and $\mathrm{Zn}$. The mean concentrations of metals and $\mathrm{CaO}$ were significantly higher than the background values of topsoil in the Changchun region, and were also higher than the mean concentrations in soils from Jilin Province, while the mean concentrations of $\mathrm{K}_{2} \mathrm{O}, \mathrm{MgO}, \mathrm{Na}_{2} \mathrm{O}$, and $\mathrm{SiO}_{2}$ were comparable to the mean concentrations in soils from Jilin Province and in topsoil from Changchun. These findings may reflect the influence of urbanization and industrialization on the areas considered. However, the concentrations of heavy metals in urban dusts from Changchun were generally lower than those recorded in other large and/or industrialized cities, particularly for $\mathrm{Cr}, \mathrm{Pb}$, and $\mathrm{Zn}$. This may indicate that the accumulation time and rate have an important influence on the content of heavy metals. $\mathrm{Pb}$ was significantly positively correlated to $\mathrm{As}, \mathrm{Cd}, \mathrm{Cr}, \mathrm{Cu}$, and $\mathrm{Zn}$. Meanwhile, $\mathrm{Cu}$ also displayed a significant positive correlation with $\mathrm{Cr}$ and $\mathrm{Zn}$. Furthermore, it should be noted that $\mathrm{Hg}$ was not significantly correlated with all other heavy metals considered.

Based on total metal concentrations and VC analysis, coupled with correlation coefficient analysis, two metal groups originating from natural and anthropogenic sources may be distinguished. Specifically, the concentration of $\mathrm{Cr}$ appears to be controlled by natural sources, whereas the levels of $\mathrm{As}, \mathrm{Hg}, \mathrm{Cd}, \mathrm{Cu}, \mathrm{Pb}$, and $\mathrm{Zn}$ in Changchun urban dusts mainly originate from anthropogenic sources. Furthermore, PCA results revealed that $\mathrm{Cu}$ and $\mathrm{Pb}$ primarily came from vehicle emissions, while $\mathrm{Zn}$ in the urban dusts came from traffic sources - especially vehicle tires. Meanwhile, Hg primarily originated from coal combustion, and $\mathrm{Cd}$ was found to be mainly associated with industrial sources inferred from the PCA, concentration level, and analogous studies in other areas. Finally, $\mathrm{Cr}$ and As were found to be mainly controlled by natural factors originating from soil dust; the influence of anthropogenic activities on the $\mathrm{Cr}$ levels was generally low. However, it should be noted that the $\mathrm{Cr}$ was positively correlated with $\mathrm{Cu}$ and $\mathrm{Pb}$ upon correlation coefficient and PCA analysis (PC2), which may imply less significant anthropogenic origins such as traffic emissions.

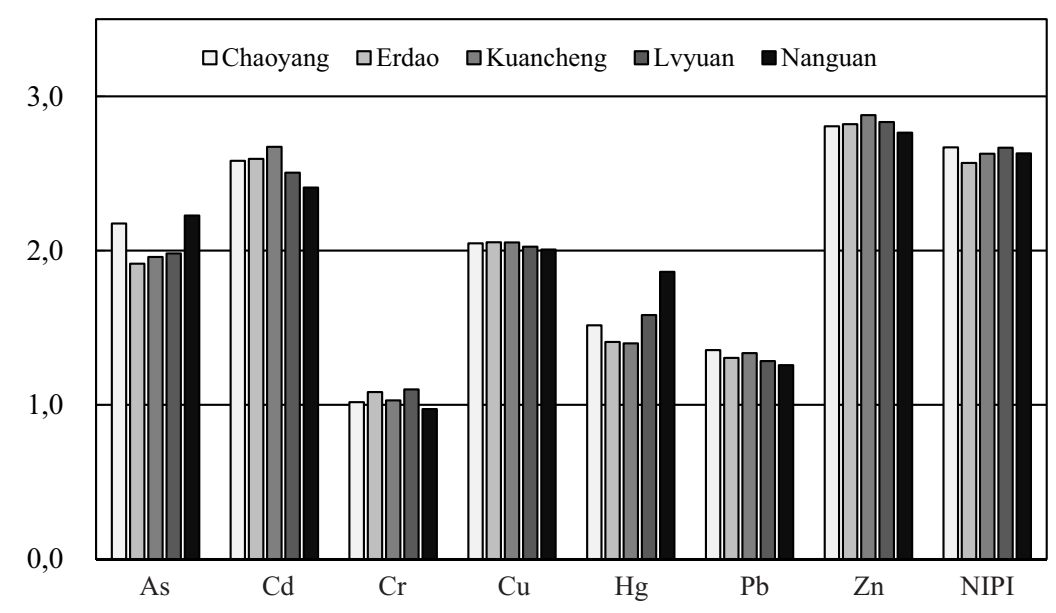

Fig. 3. The mean pollution index (PI) and Nemerow integrated pollution index (NIPI) of heavy metals in the urban dusts in different districts of Changchun City. 


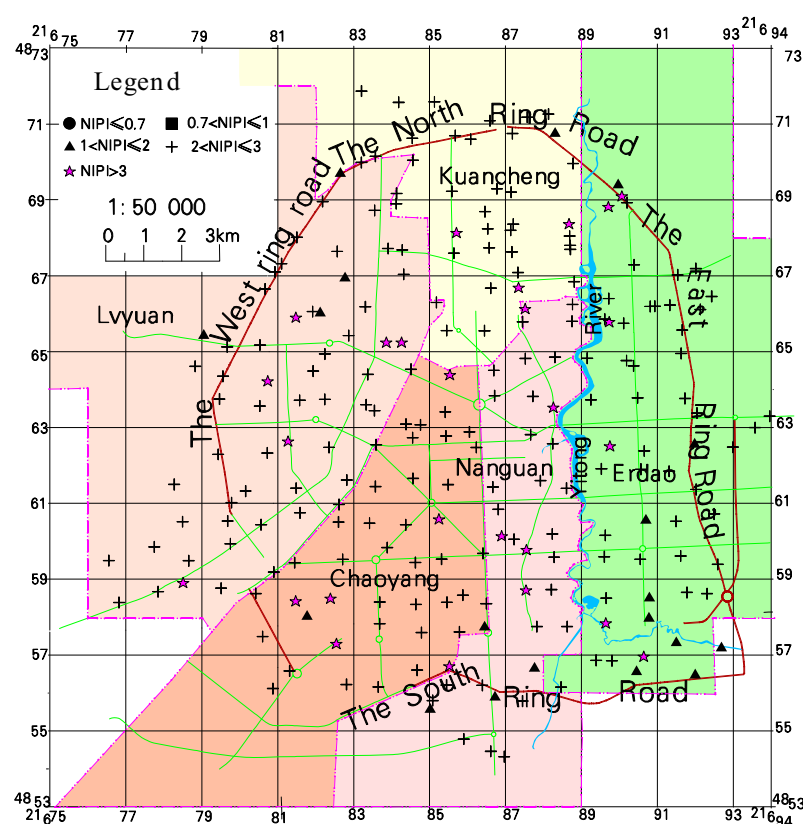

Fig. 4. Spatial distribution of the Nemerow integrated pollution index (NIPI) in the studied area.

The PI values of the metals measured in the urban dusts indicate that a significant degree of metal pollution exists in some urban dusts within the urban areas of Changchun, particularly for $\mathrm{Cu}, \mathrm{Cd}, \mathrm{Zn}$, and As. The levels are not especially high as a whole, but there are clearly contaminated hot-spot areas distributed separately in the studied region. The mean NIPI values also indicate that urban dusts in Changchun have reached the moderate level of pollution by metals. However, it should be noted that about $11 \%$ of all samples had a NIPI value above 3 , suggesting high levels of contamination by metals, particularly inside the loop road. These findings indicate that more attention should be given to metal pollution of the urban dusts in Changchun. The ecological and health implications of these findings should be considered in future investigations.

\section{Acknowledgements}

This study was financially supported by the Fundamental Research Funds for the Central Universities (No. CDJZR 12200008, and 106112013CDJZR200002). The authors gratefully acknowledge the laboratory of Changchun Inspection and Testing Center of Geology and Mineral Resources, the subordinate research institute of the Ministry of Land and Resources P.R.C., for their contribution to the analysis of the soil samples. We also thank Jia Xiaofeng, Zhai Hang, and Li Jun for their sampling and analytical work at the early stages of the project. Finally, special thanks to Elizabeth Hubbs (The University of Arizona, USA) for language editing.

\section{References}

1. WEI B., YANG L. A review of heavy metal contaminations in urban soils, urban road dusts and agricultural soils from China. Microchem. J. 94, (2), 99, 2010.

2. ZIBRET G., VAN TONDER D., ZIBRET L. Metal content in street dust as a reflection of atmospheric dust emissions from coal power plants, metal smelters, and traffic. Environ Sci Pollut Res Int. 20, (7), 4455, 2013.

3. SAEEDI M., LI LY., SALMANZADEH M. Heavy metals and polycyclic aromatic hydrocarbons: pollution and ecological risk assessment in street dust of Tehran. J. Hazard. Mater. 227-228, 9, 2012.

4. HU X., ZHANG Y., LUO J., WANG T., LIAN H., DING Z. Bioaccessibility and health risk of arsenic, mercury and other metals in urban street dusts from a mega-city, Nanjing, China. Environ. Pollut. 159, (5), 1215, 2011.

5. TAYLOR MP., CAMENZULI D., KRISTENSEN LJ., FORBES M., ZAHRAN S. Environmental lead exposure risks associated with children's outdoor playgrounds. Environ. Pollut. 178, 447, 2013.

6. HAN Y., DU P., CAO J., POSMENTIER ES. Multivariate analysis of heavy metal contamination in urban dusts of Xi'an, Central China. Sci. Total Environ. 355, (1-3), 176, 2006.

7. SHI X., WANG J. Comparison of different methods for assessing heavy metal contamination in street dust of Xianyang City, NW China. Environmental Earth Sciences. 68, (8), 2409, 2012.

8. AL-KHASHMAN OA. Assessment of heavy metals contamination in deposited street dusts in different urbanized areas in the city of Ma'an, Jordan. Environmental Earth Sciences. 70, (6), 2603, 2013.

9. LI Z., FENG X., LI G., BI X., ZHU J., QIN H., DAI Z., LIU J., LI Q., SUN G. Distributions, sources and pollution status of 17 trace metal/metalloids in the street dust of a heavily industrialized city of central China. Environ. Pollut. 182, 408, 2013.

10. LI H., QIAN X., HU W., WANG Y. GAO H. Chemical speciation and human health risk of trace metals in urban street dusts from a metropolitan city, Nanjing, SE China. Sci. Total Environ. 456-457, 212, 2013.

11. NAZZAL Y., ROSEN MA., AL-RAWABDEH AM. Assessment of metal pollution in urban road dusts from selected highways of the Greater Toronto Area in Canada. Environ. Monit. Assess. 185, (2), 1847, 2013.

12. KELLY J, THORNTON I, SIMPSON PR. Urban geochemistry: a study of the influence of anthropogenic activity on the heavy metal content of soils in traditionally industrial and non-industrial areas of Britain. Appl. Geochem. 11, (12), 363, 1996.

13. ZHU Z., SUN G., BI X., LI Z., YU G. Identification of trace metal pollution in urban dust from kindergartens using magnetic, geochemical and lead isotopic analyses. Atmos. Environ. 77, 9, 2013.

14. BI X., LIANG S. LI X. A novel in situ method for sampling urban soil dust: particle size distribution, trace metal concentrations, and stable lead isotopes. Environ. Pollut. 177, 48, 2013.

15. ZHANG C., QIAO Q., APPEL E., HUANG B. Discriminating sources of anthropogenic heavy metals in urban street dusts using magnetic and chemical methods. J. Geochem. Explor. 119-120, 60, 2012. 
16. SHI G., CHEN Z., XU S., ZHANG J., WANG L., BI C., TENG J. Potentially toxic metal contamination of urban soils and roadside dust in Shanghai, China. Environ. Pollut. 156, (2), 251, 2008.

17. HAWLEY JK. Assessment of health risk from exposure to contaminated soil. Risk Anal. 5, (4), 289, 1985.

18. ROSENFELD D., DAI J., YU X., YAO Z., XU X., YANG X., DU C. Inverse relations between amounts of air pollution and orographic precipitation. Science. 315, 1396, 2007.

19. TOKALIOGLUU Ş., KARTAL Ş. Multivariate analysis of the data and speciation of heavy metals in street dust samples from the Organized Industrial District in Kayseri (Turkey). Atmos. Environ. 40, (16), 2797, 2006.

20. CAO Z., YANG Y., LU J., ZHANG C. Atmospheric particle characterization, distribution, and deposition in $\mathrm{Xi}$ 'an, Shaanxi Province, Central China. Environ. Pollut. 159, (2), 577, 2011.

21. FUJIWARA F., REBAGLIATI RJ., DAWIDOWSKI L., GÓMEZ D., POLLA G., PEREYRA V., SMICHOWSKI P. Spatial and chemical patterns of size fractionated road dust collected in a megacity. Atmos. Environ. 45, (8), 1497, 2011.

22. ATIEMO SM., OFOSU FG., ABOH IJK., OPPON OC. Levels and sources of heavy metal contamination in road dust in selected major highways of Accra, Ghana. X-Ray Spectrometry. 41, (2), 105, 2012.

23. ADACHI K., TAINOSHO Y. Characterization of heavy metal particles embedded in tire dust. Environ. Int. 30, (8), 1009, 2004.

24. LEE PK., YOUM SJ. JO HY. Heavy metal concentrations and contamination levels from Asian dust and identification of sources: a case-study. Chemosphere. 91, (7), 1018, 2013.

25. LU SG, ZHENG YW., BAI SQ. A HRTEM/EDX approach to identification of the source of dust particles on urban tree leaves. Atmos. Environ. 42, (26), 6431, 2008.

26. SIMON E., BRAUN M., VIDIC A., BOGYO D., FABIAN I. TOTHMERESZ B. Air pollution assessment based on elemental concentration of leaves tissue and foliage dust along an urbanization gradient in Vienna. Environ. Pollut. 159, (5), 1229, 2011.

27. YANG ZP, LU WX., LONG YQ. Atmospheric dry and wet deposition of heavy metals in Changchun city, China. Research of Environmental Sciences. 22, (1), 28. 2009 [In Chinese with English abstract].

28. ZHAO XM., ZHAO LP, HUA XY. Distribution Characteristics and Sources Analysis of Heavy Metal Atmospheric Dustfall in Changchun. Urban Environment \& Urban Ecology. 22, (4), 30, 2009 [In Chinese with English abstract].

29. GUO P. Study on Heavy Metal Contamination Mechanism and Countermeasure in Urban Soil of Changchun. Changchun: Jilin University. 2005 [In Chinese].
30. YANG Z., LU W., LONG Y., BAO X., YANG Q. Assessment of heavy metals contamination in urban topsoil from Changchun City, China. J. Geochem. Explor. 108, (1), 27, 2011.

31. SHI ZM., NI SJ, ZHANG CJ. A new research of material carrier in the urban atmosphere - air dust near the ground. Guangdong Wei Liang Yuan Su Ke Xue. 14, (2), 1, 2007.

32. ZHOU F., GUO H.C., HAO ZJ. Spatial distribution of heavy metals in Hong Kong's marine sediments and their human impacts: A GIS-based chemometric approach. Mar. Pollut. Bull. 54, (9), 1372, 2007.

33. YU L., ZHANG B., ZHANG SQ. Heavy metal elements pollution evaluation on the ecological environment of the Sanjiang Plain based on GIS. Chinese Journal of Soil Science. 35, (5), 529, 2004 [In Chinese with English abstract].

34. YANG ZP. Eco-geochemical Characteristics and Sources Identification of Heavy Metal Contamination in Changchun City, China. Changchun: Jilin University. 2008 [In Chinese].

35. CNEMC (China National Environmental Monitoring Centre). The background values of Chinese soils. Beijing: Environmental Science Press of China, 501, 1990.

36. MENG XX., LI SZ. Study on the background values of soils in Jilin province. Beijing: Science Press. 1995.

37. YANG ZP., LU WX., XIN X, LI J., LI P. Lead isotope signatures and source identification in urban soil of Changchun City. Journal of Jilin University (Earth Science Edition). 38, (4), 663, 2008 [In Chinese].

38. WANG X.S., QIN Y. Environmental risk and sources of heavy metals in Xuzhou urban topsoil. Geochimica. 35, (1), 88, 2006 [In Chinese with English abstract].

39. STREETS D., HAO J., WU Y., JIANG J., CHAN M., TIAN H., FENG X. Anthropogenic mercury emissions in China. Atmos. Environ. 39, (40), 7789, 2005.

40. SHI ZM., NI SJ, ZHANG CJ. The geochemical characteristics of air dust near the ground in Chengdu. Earth and Environment. 32, (3-4), 53, 2004.

41. CHARLESWORTH S., EVERETT M., MCCARTHY R., ORDÓÑEZA., DE MIGUEL E. A comparative study of heavy metal concentration and distribution in deposited street dusts in a large and a small urban area: Birmingham and Coventry, West Midlands, UK. Environ. Int. 29, (5), 563, 2003.

42. DU Y., GAO B., ZHOU H., JU X., HAO H., YIN S. Health Risk Assessment of Heavy Metals in Road Dusts in Urban Parks of Beijing, China. Procedia Environmental Sciences. 18, 299, 2013.

43. LU X., WANG L., LI LY., LEI K., HUANG L., KANG D. Multivariate statistical analysis of heavy metals in street dust of Baoji, NW China. J. Hazard. Mater. 173, (1-3), 744, 2010.

44. WEI B., JIANG F., LI X., MU S. Spatial distribution and contamination assessment of heavy metals in urban road dusts from Urumqi, NW China. Microchem. J. 93, (2), 147, 2009. 
